\section{Bill would force journals to follow misconduct rules}

Washington. Overlooked in all the celebration over last month's passage of congressional legislation overturning the US fetal tissue research ban were a few paragraphs in an accompanying bill that, if made law, would essentially force scientific journals to adopt federal misconduct guidelines.

The language, which was passed by the House of Representatives as part of a bill to reauthorize programmes at the National Institutes of Health (NIH), directs the National Library of Medicine (NLM) to develop guidelines "...to protect against publication of manuscripts with respect to which there has been scientific misconduct...'

Although the bill does not describe what those guidelines should say (NLM is supposed to develop them in consultation with the NIH Office of Scientific Integrity and journal editors), the House staff who wrote the language say that they wanted journals to retract published articles when they are shown to be associated with scientific misconduct. If a journal refused to follow the guidelines, it would be left out of the library's abstract database. For many journals, especially specialized publications with small circulations, not being included in the NLM database is tantamount to not existing at all.

These provisions have actually been in the House NIH bill for three years. But the bill was never taken seriously because it included language to overturn a ban on the use of fetal tissue in research that the president, George Bush, had promised to veto. Although the bill passed the full House last July, it was not until last month, when the Senate passed its own NIH bill by a margin large enough to defeat a presidential veto, that people started to look seriously at the

Journal editors are disturbed by the idea language in the House bill. that Congress is telling them what to do. Daniel Koshland, editor of Science, says that his journal already has a policy to retract articles - with or without the approval of the authors - "if we are convinced they are wrong". Nature has a similar policy (see page 2).

Koshland believes that the House bill including its core definition of misconduct as acts that "seriously deviate from the standards of conduct that are recognized within the scientific community" - is more than a little ambiguous. "It's so loose and vague that I don't understand how it could be enacted", he says.

Jerome Kassirer, editor of the New Eng land Journal of Medicine, is concerned that federal guidelines would allow the government to intrude into an evolving system of self-regulation. Most universities already have misconduct guidelines, he says, and they alert journals to research that may be the subject of misconduct investigations.

Many medical journals have also adopted misconduct guidelines developed last year by the International Committee of Medical Journal Editors. George Lundberg, editor of the Journal of the American Medical Association, says that congressional efforts to develop similar rules "are unnecessary and stand a chance to do more harm than good". Federal guidelines are particularly inappropriate for non-US journals, he says: "By trying to legislate how [the NLM] should work in regard to journals outside the United States, the Congress is sticking its nose where it does not belong."

Later this month, the House and the Senate will meet in conference to work out the differences between the two versions of the NIH bill.

Christopher Anderson

\section{Universities fear being left out by patent reforms}

Washington. A US university technology transfer association told Congress last week that plans to harmonize the US patent system with the rest of the industrial world could leave academic researchers unable to patent many of their inventions. Without special protections for universities and independent inventors, it argued, the planned US move from a 'first-to-invent' system to a 'first-to-file' system would favour companies that can afford expensive legal and filling fees.

The United States is negotiating with European nations and Japan as part of an international patent treaty process that would create uniform rules in all the major industrialized nations (see Nature 356, 645; 23 April 1992). At a joint House-Senate hearing last week, legislators heard testimony from patent experts and industry and university representatives on two bills that would change US patent law along the lines of the expected treaty resolution.

Howard Bremer, a lawyer representing the Association of University Technology Managers, pointed out that the work of academic researchers is especially vulnerable to changes in the patent system. University inventions are usually based on basic research and tend to be 'seminal', he said. If precedence goes to the first to file, university researchers may be forced to submit patent applications before they know the full utility of their invention. Worse still, he said, they may decide they cannot afford to file at all.

Large companies often have the resources to file applications to cover any discovery, however minor. If universities are forced to file early on basic discoveries, companies could build on the invention and file for uses that might not have occurred to the university researchers.

The current US system allows university researchers to file for a patent as long as a year after they publish a discovery. Both the bills in Congress and the draft international treaty include a similar 12-month 'grace period' after publication, during which an inventor would still be able to claim a patent.

Bremer said that acceptance of such a grace period by the rest of the world would calm the fears of most US universities. US academics also favour that portion of the British patent system that allows for a lowcost 'provisional' patent application, to be followed with a larger fee if the inventor decides to pursue the patent. Such a clause, Bremer said, would give universities time to choose the inventions they want to pursue without risking their patent rights.

Christopher Anderson
Christopher Anderson

Finding a Balance: Computer Software, Intellectual Property and the Challenge of Technological Change. OTA, 1992. 